\title{
Global Coordination and Regulation of Tourism: Radicalizing Kant's Cosmopolitanism
}

\author{
Coordinación global y regulación del turismo: \\ una radicalización del cosmopolitanismo de Kant
}

TAZIM JAMAL (Texas A\&M University) and JAUME GUIA (Universitat de Girona, University of Johannesburg)

Artículo recibido: 6 de julio de 2020

Solicitud de revisión: 15 de octubre de 2020

Artículo aceptado: 28 de octubre de 2020

Jamal, Tazim and Guia, Jaume (2020). Global coordination and regulation of tourism: Radicalizing Kant's cosmopolitanism. Recerca. Revista de Pensament i Análisi, 26(1), pp. 9-31. doi: http://dx.doi.org/10.6035/Recerca.2021.26.1.2

\begin{abstract}
Tourism is a complex phenomenon in scale and scope. Interrelated with other systems (ecological, social, economic, political) from the local to the global, its impacts and effects transcend borders, making coordination and regulation highly challenging. Global mobilities (both physical and virtual) and neoliberal globalization further complicate enabling just and sustainable tourism. New forms of governance are needed to address global threats like climate change and pandemics. This paper explores Immanuel Kant's transcendental perspective on "perpetual peace" and traces his evolving cosmopolitanism over a decade of essays. We then turn towards what appears to be a contradictory, immanent posthumanist approach from Gilles Deleuze. Radicalizing Kant using Deleuze leads to a different concept of 'normativity', grounded in an ideal of perpetual self-critique and self-creation. Such a critical, affirmative ethic opens possibilities for situated approaches to cosmopolitan rights and global justice, rather than global regulatory structures to coordinate effective and proactive actions.
\end{abstract}

Key Words: tourism, regulation, cosmopolitanism, Kant, Deleuze.

\section{Resumen}

El turismo es un fenómeno complejo tanto en términos de escala como de alcance. Interrelacionado con otros sistemas (ecológicos, sociales, económicos, políticos) de lo local a lo global, sus impactos y efectos trascienden fronteras, lo cual hace que su coordinación y regulación sea un enorme reto. La movilidad global (tanto física como virtual) y la globali- 
zación neoliberal complican aún más la posibilidad de un turismo justo y sostenible. Se requieren nuevas formas de gobernanza para poder abordar amenazas mundiales actuales como son el cambio climático y las pandemias. Este artículo explora primero la perspectiva trascendental de Immanuel Kant sobre la «paz perpetua» y traza su evolución del cosmopolitanismo durante una década entera de ensayos. Seguidamente, se adopta un enfoque poshumanista e inmanente como el de Gilles Deleuze. La radicalización que hace Deleuze de Kant conduce a un concepto diferente de «normatividad», basado en un ideal de autocrítica y autotransformación perpetua. Una ética crítica y afirmativa como esta abre nuevos caminos hacia una aproximación más situacional a los derechos cosmopolitas y la justicia global, en lugar de simplemente profundizar en estructuras regulatorias globales, para la coordinación de acciones más efectivas y proactivas.

Palabras clave: turismo, regulación, poshumanismo, cosmopolitismo, Kant, Deleuze.

\section{INTRODUCTION}

As the critical geographer David Harvey put it, we live in a world of "time-space compression" (Harvey, 1990) where time has speeded up and space has shrunk under rapid mobilities, images, and news from a globalized media. The world seems a smaller place, as the ability to experience diverse places, environments and cultures physically and "virtually" open a different relationship to the world - a form of cosmopolitanism that evolves with every journey where one negotiates differences between being grounded somewhere and traveling elsewhere. Pre-COVID-19, globalization was a bustling marketplace of rapidly transferred goods and services, workers and tourists, finance and investment, aided by digital technologies, the sharing economy and online sharing platforms. Transnational corporations facilitated by multilateral alliances and free trade agreements created growing neoliberal capital markets that swiftly transcended state borders.

What governance responsibilities arise under such mobilities and porous boundaries? While taking care of the local and environments within borders calls on civic duties, responsibility toward places beyond borders raise questions of global justice and global citizenship (see Bianchi and Stephenson, 2014). COVID-19 reveals the immense economic inequalities and disproportionate burden placed on vulnerable populations, the elderly, the poor, migrants and refugees, along with immense losses in the service economy as borders slammed shut once the pandemic was announced on March 11, 2020 by the World Health Organization (WHO). Slow re-opening (rapid for some) raise opportunities for beleaguered destinations seeking economic recovery, 
but not at any cost. Venice already faced hordes of area-based visitors in early June. Local Venetians protested against neocolonial cruiseship exploitation and the crushing overtourism that beset many popular destinations worldwide - a livable city (rents are high), de-growth and de-marketing are sought by various residents (Horowitz, 2020). ${ }^{1}$

Restoring travel and tourism towards more sustainable futures is a pressing challenge from the local to the global. Global threats like climate change require concerted global action to address highly stressed ecosystems, species extinctions, as well as climate injustice. Philip Alston, UN special rapporteur on extreme poverty and human rights, warns that lack of action on climate change will undermine basic rights to sustenance for hundreds of millions of people, and threaten democracy and the rule of law (Alston, 2019). Unfortunately, coordinated crisis management and communication plans have rarely been implemented effectively. At a time when close collaboration was needed between tourism and the health authorities locally to globally, and despite lessons from the 2002-2003 SARS pandemic, destinations, operators, travelers and service industry workers were left unprepared. The United World Tourism Organization (UNWTO) and global bodies like the World Travel and Tourism Council (WTTC) and the Cruise Lines International Association (CLIA, the world's largest cruise industry trade association) failed to react swiftly to the unfolding crisis in China in January and while cruise ships like the Diamond Princess began to succumb to SARS-CoV-2. Almost two months after China officially informed the WHO of a novel coronavirus on Dec. 31, 2019, a joint statement was issued by WHO and UNWTO, and a Global Tourism Crisis Committee was set up by the UNWTO after a highlevel virtual meeting on March 25 of stakeholders including WHO (Modern Diplomacy, 2020; WHO, 2020). Transnational operators like cruiselines continued to operate well into April before grinding to a halt.

Growth-driven and mired in neoliberal ideology (Bianchi and de Man, 2020; Gössling, Scott and Hall, 2020), it is not surprising that the UNWTO was late to respond to the unfolding crisis in travel and tourism (see the UNWTO's call to action now: https://www.unwto.org/tourism-covid-19). Various countries adopted their own pandemic plans and vulnerable populations

Toto Bergamo Rossi, head of the Venice Heritage Foundation prepared an open letter on behalf of "citizens of the world" for his organization to send to the Italian government. "Co-signed by museum directors and academics, and also by Mick Jagger, Francis Ford Coppola and Wes Anderson, the letter presents "Ten Commandments" for the new Venice, including stricter regulation of "tourist flow" and the Airbnb market...” (Horowitz, 2020). 
in the Global North and Global South have been hit hard. Novelli, Burgess, Jones and Ritchie (2018) noted that few studies have addressed health-related crises in developing countries and even fewer have addressed the indirect threat of epidemics on their tourism industries. Mair, Ritchie and Walter's (2016) review of crisis management reports similar lack of preparation, information and collaboration:

[...] knowledge sharing and collaboration within the industry is seen as vital [...] However, there is little evidence from the studies in the review to suggest that this has been taking place. Indeed, much of this review has focused on a lack of existing crisis management plans, lack of communication and reactive responses (Mair, Ritchie and Walter, 2016: 19).

The global reach of tourism makes such crisis preparation challenging for threats that extend across borders. Furthermore, tourism is intricately interwoven with other systems from the local to the global (ecological, economic, social and political). Are new forms of governance needed to address global threats, ranging from geopolitical conflict and terrorism to global environmental and health crises? Political philosopher Nancy Fraser says:

We must ask: If the modern territorial state no longer possesses the administrative ability to steer "its" economy, ensure the integrity of "its" natural environment, and provide for the security and well-being of "its" citizens, then... By what means can the requisite administrative capacity be constituted and where precisely should it be lodged? If not to the sovereign territorial state, then to what or whom should public opinion on transnational problems be addressed? (Fraser, 2010: 98 ).

Seventy-five years ago, in San Francisco, a charter was signed that created the multilateral alliance called the United Nations. Unlike the League of $\mathrm{Na}$ tions set up after $\mathrm{WW}_{1}$ to manage conflict and prevent wars between countries, etc., it has survived, its membership has grown to ${ }_{193}$, but it is subject to bureaucratic incompetence, the increasingly dominant stature of China (which pays $12 \%$ of the UN budget) and weakening US leadership (The Economist, 2020). From a tourism perspective, López-González (2018) argues that the rights and impacts related to global tourism cannot be supported and defended by ethical frameworks such as the UNWTO's Global Code of Ethics. A legal framework - an international convention — is also needed. He calls for revisiting German philosopher Immanuel Kant's work on perpetual peace, which strongly influenced the formation of the League of Nations. 
Kant's notion of cosmopolitan right in Towards Perpetual Peace (1795) attempted to capture theoretically the fact that peace requires legal regulation and rule of just laws not simply within the state, and between states, but also for interactions between states and foreign individuals or groups. ${ }^{2}$ Scholars continue to debate the continued theoretical and practical relevance of Kant's essay, and "[a]ccelerating globalization also gives these reconstructions and reappraisals of Kant's cosmopolitan ideal a new urgency" (Bohman and LutzBachman, 1997, back cover). ${ }^{3}$ The main purpose of this paper is to review Kant's notions of perpetual peace and his evolving cosmopolitanism, and discuss this in relation to other possibilities for governance of global tourism. Of particular merit, we argue, is a radicalizing of Kant's transcendental idealism for a grounded, immanent posthumanist perspective on a cosmopolitan ethic to guide tourism: Gilles Deleuze's affirmative ethic and critique as a way of life. Implications for global tourism governance, pedagogy and praxis follow.

\section{TOWARD PERPETUAL PEACE AND THE COSMOPOLITAN IDEAL}

What is peace? Can genuine peace be realized? Immanuel Kant [1724${ }_{1804}$ grappled with this for over a decade in various writings, including his early essay "Idea for a Universal History with a Cosmopolitan Aim" $(1784$, Idea henceforth) and his popular essay "Toward Perpetual Peace" (1795; TPP henceforth). This section briefly summarizes Kant's evolving cosmopolitanism as revealed in three themes that run through them: morals, with respect to the well-being of the human being, politics and the well-being of states, and thirdly a cosmopolitical perspective with respect to the well-being of the human race as a whole. These works offer a rich insight into Kant's cosmopolitanism as it evolved from Idea in 1784 to his vision of perpetual peace over a decade later in TPP (1795).

2 Kleingeld and Brown (2014) explain that the word "cosmopolitan" derives from the Greek word kosmopolitês ('citizen of the world'), and 18th-century cosmopolitan views like that of Kant understood cosmopolitanism to imply a positive moral ideal of a universal human community.

3 In the context of tourism, see Edgell, Allen, Smith and Swanson's (2008) comprehensive discussion of global tourism policy, international tourism institutions and tourism as a policy for peace, where they note Kant's essay on perpetual peace (Kant, 1795). 


\subsection{The cosmopolitan plan in Idea (1784)}

In Idea, Kant spells out a number of propositions for enabling a stable, good state and the further development of human capacity for the use of reason, thereby to culminate in moral agency and our full development as moral beings, noting it could take generations of human beings to accomplish. Nature has given us reason and freedom of will grounded upon reason to accomplish her "final purpose". Reason is self-directing (we are self-thinking, autonomous beings) and guides us progressively towards the moral law and exercise of good will. Kant appears here to be setting the ground for a cosmopolitical history oriented towards a kingdom of ends, a term he elaborated in the Groundwork of the Metaphysics of Morals (Kant, 1785), published shortly after Idea. ${ }^{4}$

For all rational beings stand under the law that each of them should treat himself and all others never merely as means, but always at the same time as ends in themselves. But from this there arises a systematic union of rational beings through common objective laws, that is, a kingdom which can be called a kingdom of ends (admittedly only an ideal) because what these laws have as their purpose is just the relation of these beings to one another as ends and means (Kant, 1785, 4: 433).

Being in accord with the principles of universal laws is a practical necessity, i.e., a duty, which applies not just to the head but to each and every member of the kingdom in equal measure, says Kant. To progress towards such "perfect development" as an ethical community, however, requires peace between individuals and states. For this, a regulative civil condition needs to be established, to facilitate not just peace within states but peace between states (a necessary condition to peace within the state, for how could this be possible if the citizens are at war with another country?). The political community operates under principles of rights and justice to guide external conduct; the ethical community is guided by the moral law -following the maxims and principles that accord with universal moral laws.

Kant introduces here his idea of a cosmopolitan union. Peace within and between states is important to achieve the highest good (happiness in accord with the moral law). But enabling a universal Civil Society is immensely difficult he laments: Man requires a master and the master also requires a master,

4 Morality "consists in the references of all actions to the lawgiving by which alone a kingdom of ends is possible” (Kant, 1785, 4: 434). 
but a perfect solution is impossible, he says: "out of wood so crooked and perverse as that which man is made of, nothing absolutely straight can ever be wrought" (proposition 6, Idea). A regulative idea is needed to establish a perfect Constitution of Society, i.e., international laws. The same "social unsociability" that drives citizens to eventually create a "commonwealth" is what causes the commonwealth in its external relations to seek (in self-interest) inter-state peace by entering into a "federal league of nations", a "great confederation", a "civil constitution founded upon law" (proposition 4, Idea). Moreover, he notes, states are so interconnected and linked in many parts by trade that civil liberties, sources of livelihood and trade must be permitted to flourish if the state is to progress internally and externally. While theoretical, nothing empirical in practice suggests to Kant that the Cosmopolitic State he envisions here is not possible to instantiate.

\subsection{Toward Perpetual Peace (1795)}

Kant elaborates on the cosmopolitical project raised in Idea over a decade later in TPP (1795). Some important themes from Idea are raised in his essay Common Saying (1793) on the way to TPP. The very opposition of inclinations to each other, from which evil arises, he says in Common Saying, provides reason free play to facilitate the rule of good. The need arising from constant wars, too, must bring peoples and states to enter into a political union. Kant warns, too, against forming a singular entity (a cosmopolitan constitution) that risks becoming despotic (a theme he repeats in TPP): 5

a cosmopolitan constitution, or else if this condition of universal peace is still more dangerous to freedom from another quarter, by leading to the most fearful despotism..., this need must still constrain states to enter ... a rightful condition of federation in accordance with a common agreed upon right of nations (Kant, 1793, 8: 311).

In TPP Kant presents regulative conditions and definitive articles of perpetual peace. The only way that states can leave their lawless or warlike condition is to join a public coercive system of laws. The highest good is a well-ordered civil union within and between nations - a state of peace within and between nations must be established (rather than being in a state of war, which is the

John Rawls in The Law of Peoples echoes Kant's concern that a world government, i.e., "a unified political regime with the legal powers normally exercised in central governments would be a global despotism or a form of failed state" (Rawls, 1993: 46). 
more natural state). The right of nations shall be based on a "federalism of free states", like a "league of nations, which, however, need not be a state of nations" (Kant, 1793, 8: 354), or a "pacific league (foedus pacificum)" which is distinct from a one-time peace pact as it aims to ends all war forever (Kant, 1793, 8: 356). The practical, objective reality of such a federalism, he says, should extend over all states, and a powerful, enlightened republic of peoples could provide a focal point for other states to join such a federative union.

Just institutions at the level of the state and between states, are not enough, however. Interactions between states and between individuals, groups and states must be considered, i.e., public rights (Kant, 1793, 8: 360). Kant has become sensitive to colonial injustices of civilized, commercial states oppressing, occupying, and conquering foreign lands (e.g., in the discovery of the Americas, Spice Islands, the Cape, East Indies, etc.). He refers to the Sugar Islands as "that place of the cruelest and most calculated slavery" (Kant, 1793, 8: 359). And he recognizes the growing interdependence of economic systems and trade between societies, where economic harmony is necessary for the well-being of the citizens of a state, and hence for peace. He argues therefore that republican and international rights plus a cosmopolitan supplement are a necessary condition for perpetual peace in such an interrelated world:

Since the (narrower or wider) community of the nations of the earth has now gone so far that a violation of right on one place of the earth is felt in all, the idea of a cosmopolitan right is ... a supplement to the unwritten code of the right of a state and the right of nations necessary for the sake of any public right of human beings and so for perpetual peace (Kant, 1793, 8: 360).

The Earth belongs to all human beings by virtue of the right of common possession of the earth's surface and "originally no one had more right than another to be on a place on the earth." (Kant, 1793, 8: 358). As it is a "sphere", we cannot distance ourselves infinitely from each other but must put up with the proximity of the other. Perpetual peace requires forming a rightful (legal) constitution in accord with the rights of citizens of a state founded on representative and republican principles), a second one in accord with the rights of nations that determines relations among the nations, and a third one in accord with the rights of citizens of the world, where individuals and states standing in external relations to each other are to be regarded as "citizens of a universal state of mankind (ius cosmopoliticum)" (Kant, 1793, 8: 349). 
Kant seeks here to establish a public right, specifically, a Cosmopolitan Right (CR) limited to conditions of universal hospitality. CR speaks to nonhostility in the relationship between visitor and inhabitant. The visitor has the right to present herself and the resident has the right to refuse interaction - the stranger can claim the right to visit, but not the right to be a guest (Kant, 1793, 8: 358).The resident can turn the visitor away as long if it does not endanger the visitor's life to do so. If interaction is permitted by the resident, the visitor then has the right to offer to engage in commerce (but not to engage in it unless permission is provided).

In this way distant parts of the world can enter peaceably into relations with one another, which eventually become publicly lawful and so finally bring the human race even closer to a cosmopolitical constitution (Kant, 1793, 8: 358).

Kant's public right to hospitality is closely tied to peaceful commerce and trading as flourishing would be difficult if these were to wither, he says. They are crucial for the well-being of nations and their people. But his emphasis on "the 'spirit of trade', which he calls the 'guarantee of cosmopolitan law' (Kant, 1795, 8: 365 ) is problematic. As Kleingeld (1998: 82) points out, it provides no satisfactory solution: "there is nothing in the pursuit of commercial gain as such that implies that hospitality rights for all humans (not just sales representatives, but also philosophers, tourists, refugees, and others) will be the inevitable spin-off."

\section{GLOBAL JUSTICE FOR A SOCIALLY ACCELERATED TOURISM?}

As shown above, Kant's notion of perpetual peace evolves as he grapples with the ideal of a universal human community striving towards perfect moral development in Idea (Kant, 1784). The Cosmopolitan Right he presents in TPP in the form of hospitality attempts to curtail the violations that can occur as human beings travel and attempt to engage in communication and commerce. There is, too, the potential risk of trouble and violence that one place on our

6 The tension between cosmopolitan rights as moral rights rather than commercial and political rights such as Kant forwarded has been discussed in tourism with respect to the public's rights to travel and cross borders as individuals, refugees and global citizens, versus the state and industry's rights to protect and gain commercial and political benefit. In addition to Bianchi and Stephenson's (2014) in-depth exploration, see, for instance, Swain $(2009,2013)$. 
globe to be felt all over it, as he notes. Yet, it would seem that more than cosmopolitan rights such as provided by Kant is needed in the socially and environmentally (viruses in tourist bodies!) accelerated domain of global tourism. A commercial cosmopolitan right (CR) of refusal/entry is inadequate in the globalized stage where transnational corps (TNCs) slip through neoliberal porous borders (not porous in Kant's time nor subject to virtual and physical mobilities of today). Appropriate political and institutional forms are necessary to establish not just international laws, international human rights commissions and international criminal courts, but also for a cosmopolitan global justice system that addresses rights and responsibilities associated with global mobilities and global impacts of the actions of transnational corporations and nation states on the shared earth and its inhabitants (human and non-human others). These are not merely economic and social impacts, but also to do with cultural commodification and exploitation (see Horkheimer and Adorno, 2002), and tourism as a system of consumption and production from the local to the global is one avenue in which such cross-border issues and injustices arise.

It can be argued then the political initiatives and guarantees of Cosmopolitan Right and Cosmopolitan Law should include the formation of institutional governance and legal structures to better address cosmopolitan rights and justice in a local-global tourism system, i.e., global justice (in tourism). Justice in this context encompasses cultural as well as economic and social justice issues that are systemically and institutionally engrained, such as related to ethnic and indigenous rights violated under colonialism and settler colonialism, biopiracy, global food security and climate refugees, etc. But what form should such a cosmopolitical justice take?

\subsection{Re-envisioning cosmopolitan rights and cosmopolitical justice}

How can governance of a global tourism industry be enacted to enable the good of tourism, redress injustices that are beyond the capabilities of individual countries and groups, and sustain the health and well-being of the planet and its inhabitants? What sort of political structures are needed to ensure the good of travel and tourism, which are so intricately interwoven

See, for instance, Britton's well-cited work on dependence and underdevelopment in the political economy of tourism in the 'Third World' (1982), and Wood (2009) on neoliberalism and related injustices in the global cruise industry. 
with local to global economic, social, ecological, and political systems? Concerned about despotism and other issues related to one-world government, Kant political cosmopolitanism calls for a federation or alliance of states. But consider this multi-lateral alliance of nations: the United Nations and its tourism, the UNWTO. They lack regulatory teeth, and initiatives like their Sustainable Development Goals are criticized as neoliberal agendas (Bianchi and de Man, 2020; Mowforth and Munt, 2016). López-González (2018) situates the UNWTO as a heir of Kantian cosmopolitanism, but argues that neoliberal globalization has co-opted the whole system and moral frameworks are insufficient. The move from the ethical code to the framework convention can also be seen as another move by neoliberal utilitarianism to further co-opt deontological and moralistic concerns, argues López-González (2018).

One can easily come up with a list of worries and debate the challenges of creating a global entity that is needed to regulate international tourism, and also to provide effective coordination and rapid response during crises like the current COVID-19 pandemic. One option is to enact transnational public spheres to govern the immense reach and scope of tourism across borders. A public sphere across borders, whether it is one global public sphere or a number of transnational public spheres (TPSs) is a highly challenging proposition, however. Examples of public spheres are present in various collaborative approaches to tourism-related planning and policy within borders (see, for instance, Dredge \& Jenkins, 2016; Hall, 2011), but what would this look like across borders? It would entail creating new, transnational public powers, and making them "accountable to new democratic transnational circuits of public opinion" (Fraser, 2010: 99). Given the complexity of global tourism, this would be a daunting task to consider. A number of TPSs rather than one may need to be envisioned, enabling the participation of various social movements, civil society organizations (including NGOs), and other publics. And, here, too, global mechanisms for democratic communication would be needed to enable citizens worldwide to make these tourism related TPSs accountable and attentive to not just general principles of justice, but also particular principles for locally situated cultural and historical contexts.

Some form of global organization to coordinate and regulate tourism to ensure justice and fairness, towards the end of good tourism (see Jamal, 2019), sounds attractive in theory but how well can it work in practice? Kant appears to recognize that his project of perpetual peace cannot be fully achieved on theoretical grounds and draws on moral ideals to advance perpetual peace through a universal human community (Kant, 1795, 8: 360-362, 368). Human 
beings are rational beings and ends in themselves, ${ }^{8}$ their external freedom should therefore be protected and their happiness set as ends by all rational beings. We therefore have a moral duty to bring about an ideal civil constitution and perpetual peace, says Kant. Here, his transcendentalism and his reliance on moral ideals both come under question.

Social-political theorist Juergen Habermas and others have criticized Kant's reliance on moral principles and argue for a stronger form of transnational governance, but debate continues on what this might constitute (see Habermas, 1997, Kleingeld, 20o6; López-González, 2018, Nussbaum, 2019; Young, 2006). But more is needed here? Is it to focus on organizational and regulatory structures to enable global political justice? Or can global justice be better envisioned as exploring the tension between the "general" and the "particular"? Following from earlier critiques of hospitality in TPP, Kant's proponents must find a way to strengthen CR beyond commercial right of refusal. His transcedentalist, universalist cosmopolitan history offers a compelling argument, but in the 21st century of rapid physical and virtual mobilities, neoliberal globalization, pluralistic voices resisting Eurocentric, modernist values, (neo)colonialism, and the Anthropocene, it would seem that new designs are needed, as Escobar (2018) argues. Can Kant's cosmopolitan vision of perpetual peace open new ways to explore being good citizens and travelers of this world community? What would a radical, immanent view towards a particular, situated ethic offer to re-envision cosmopolitan rights and justice in a local-global tourism domain? Guia (2020) propose an alternative vison based on a posthumanist Deleuzian ethic, which we explore further below.

\subsection{An affirmative ethic based on critique as a way of life}

Guia (2020) argues that if justice tourism wants to move beyond the dominant neoliberal, consumerist and liberal logics that pervade tourism, it must become aware of underlying dominant ethics and of the potential of radical transformation for justice in and through tourism. He argues for a posthumanistic, Deleuzian affirmative ethics that is immanent (not transcendent), relational (not institutional) and political (not moralistic). His approach embraces both inclusiveness and attentiveness to the local and particular, and to social-political action. For tourism to effectively contribute to justice and the expansion of justice tourism, travelers, hosts and operators must learn to be-

8 See Humanity Principle in the Groundwork (Kant, 1785). 
come political and act politically; learn to become the "other", to become "minoritarian, to embrace ethical encounters with difference, and to live inclusively of non-human others -in other words, embrace an immanent posthumanist perspective. Posthumanism offers an ethical regime that can battle universal commodification and Deleuzian affirmative ethics offers a radical transformation as well as a truly alternative form of globalization (Guia, 2020).

While Kantian morality presents a set of binding and stable rules that judge actions and intentions in the light of transcendent values, Deleuze's ethics is not moralistic. Ethics for Deleuze consist of modes of behavior that sustain a mode of existing or way of life. Ethical worth can be judged without the need of universal values, by purely immanent criteria like whether modes of behavior increase the capacities to affect and be affected, developing and transforming the self to attain a certain mode of being in response to the environmental and social conditions. Moreover, it is an affirmative ethics, namely an ethics of willing in a manner that involves neither resignation nor resentment, but rather, affirmation. Responsibility takes a different meaning here, it is an ethics of meeting other bodies in response-ability (Haraway, 2008), without domination or exploitation. As such, it is an ethics of relational virtuosity, a relational approach that eschews formal 'regulations'.

Kantian ethics seems at odds and far removed from Deleuze's. Yet, Deleuze founds the inspiration for his ethics precisely in Kant's idea of critique and his theory of faculties. Like Kant, Deleuze does not just mean 'critique' in the vague sense of any evaluative analysis, but as an examination of the structure and limitations of the faculties. However, unlike Kant, critique is not merely interested in disciplining the faculties when they exceed their limits, but in the faculties realizing their power up to their limits (Deleuze, 2008). For Kant, what subjects experience is determined by what they can experience, that is, by their faculties, where these are not actual experience but, rather, the conditions of experience. In this way he transforms the problem of the relationship between subjects and objects into a problem of the relation between faculties (Carr, 2018). By contrast, Deleuze's immanent critique focuses on the internal forces of the faculties, which are now seen as capacities (relations of force) instead of mere conditions of experience (mental phenomena). Therefore, for Deleuze, faculties do not belong to subjects, rather, "subjects are precipitated from faculties" (Bryant, 2008: 97).

Moreover, faculties do not express a human nature, they express the power of time and repetition within particular cultural heritages found in the 
forces of language, history, social and political mechanics, and images of thought'. To create real thought freed from the constraints of representation, the real interplay of faculties constitutive of common sense beneath the supposed unity of the subject must be revealed. Deleuze's critique subverts the necessity of an assumed common-sense harmony and reveals the real interplay of powers beneath the dogmatic image of thought implicit in the Kantian critique. Deleuze's theory of faculties is thus an attempt to produce a 'thought without image' by means of an immanent version of Kantian critique to the faculties when experiencing encounters, that is forms of difference that transmit a 'shock' or 'violence' from sensibility to thought (Deleuze, 1994: 165).

Therefore, the radical critique of the dogmatic image of thought puts into question all presuppositions and everything that is considered given, while the dogmatic image of thought, which operates as a means of assigning legitimacy on the basis of a comparison with what is already known, disqualifies anything that is perceived as too foreign. It can be argued then that this conventional way of thinking about thought lies at the basis of the exclusionary and exploitative practices to which supremacists have subjected the rest of the world for centuries. In Carr's own words (2018: 37):

The claim that recognition is thinking at its most natural and universal is not a harmless observation, but a strategic interpretation with an ulterior teleological motive -the conservativeness of which diminishes and enslaves thought, enslaves us as thinkers, and enslaves others who are perceived as unrecognisable, that is, as those whose perspective and experience of the world does not match the way we have been habituated to seeing it.

Contrarily, thinking without an image is the constant re-evaluation of learning that has become sedimented into knowledge, an eternal ungrounding of thought by thought. The fundamental ethical imperative in Deleuze's work is to find a way for thought to think difference rather than repeat the same. This has important consequences for the concept of normativity, where Deleuze and Kant are at odds with each other. Kant's normativity is traditionally understood to be structured around a number of principles drawn from a sense of the good, where the ethical law is produced through submission to a central, pre-defined governing power. It then establishes the borders "of what counts as respectable, acceptable and workable as a set of operative norms and values both in society and in scientific, philosophical and cultural practice" (Braidotti \& Pisters, 2012). Conversely, for Deleuze, and because the subject is not a unified, individualistic and autonomous agent, the appeal to 
normativity based on universal principles is irrelevant. His nomadic normativity is creative, process-oriented and critical of despotism and negativity, thus affirmative.

While it is sometimes argued that Deleuze is the "anti-normative theorist par excellence" (Colebrook, 2012: 81), the emphasis on creation indicates a strong normative orientation in Deleuze's thought. The normativity at issue in Deleuze is evaluative, but without an unchanging, dogmatic goal. The normative ideal is one of a progress toward openness that can, however, never be complete because it is always practiced alongside the habit of creating habits, of constant reterritorialization. The norm expresses immanence, rather than the transcendence of universal norms, and emphasizes the genesis of emerging, affirmative values, rather than the implementation of canonical laws. So the problem is not with norms, but with negative ones and with the assumption that they are true (Carr, 2018).

Therefore, Kant's transcendental method is radicalized by Deleuze (2008), and leads to a totally different concept of 'normativity', grounded in an ideal of perpetual self-critique and self-creation. This clandestine Kantian critique made by Deleuze is with the purpose of developing a new ethical practice -the idea of critique as a way of life in the world. On one hand this method of radicalizing Kant's theory of faculties brings Kant and Deleuze closer together. But on the other hand it means rejecting the conventional or standard understanding of Kantianism, and embracing the Deleuzian re-interpretation of Kant, towards a new ethical paradigm of affirmative self-critique.

So, is it possible that Deleuzian affirmative critical selves might populate a new kind of federation to govern global tourism, a less permanent and less 'universalizing' hybrid, whose 'norms' or 'territorializations' are temporary stages for future critique and de(re)territorializations? A globalized amorphous unitary platform (federation) of clusters of affirmative-critical selves (sociopolitical movements), detached from identity politics and from 'universal' notions of regulation? Such a utopian view would represent a 'hybridized' form of cosmopolitical governance characterized by 'intersectionally transversal' and 'posthumanistically' pedagogical movements. Move-ability and intersectionality would be necessary, otherwise the system could revert to old tribalism and Kant's worry about despotism would lurk on the horizon if territorializations won the struggle for global justice. 


\section{IMPLICATIONS FOR TOURISM GOVERNANCE, PEDAGOGY AND PRAXIS}

Kant's ideas of respect for humanity and rights to freedom have influenced international human rights movement, and many national legal and constitutional frameworks as well as international organizations like the United Nations, which drew from his vision of perpetual peace. Much further work is needed to offer a clearer theoretical argument for a cosmopolitan ideal of global justice to help govern for just tourism beyond borders, but practically, at least, the urgency for global coordination and regulation of tourism needs to be addressed. Global crises like climate change and pandemics threaten ecological and social sustainability, inequities are rising and impacting the equal dignity of human beings who are affected by tourism, e.g., with respect to decent work in precarious economies and lack of accountability of neoliberal institutions and organizations (Bianchi and de Man, 2020). But do such just aims require institutional structures for global justice, one of many forms, such as Kant envisioned for his universal cosmopolitan history and perpetual peace? Or can a posthumanist ethic of critique (and care) as a way of life advance local, situated, particular ethics for a pluriverse (rather than a monoverse) of ways of relating (Escobar, 2018) and governing travel and tourism in the $21^{\text {st }}$ century?

There is hope in pedagogy and praxis, it is not simply utopianism in the posthumanist approach advanced above. Tourists embracing a Deleuzian affirmative ethic and (self-)critique as a way of life offer new possibilities for being informed, engaged global citizens, embracing difference and diversity, exercising situated response-ability (Haraway, 2008) towards home and the world. They share the same globe as residents and travelers, as Kant pointed out in his attempts to situate hospitality and the cosmopolitan right to travel.

A posthumanist approach comports with local and Indigenous ways of knowing and being, and offers a counter-perspective to political cosmopolitanism for addressing global threats to tourism, such as climate change. Wainwright and Mann (2018), for instance, explore whether a planetary sovereign may arise for planetary management of climate change, or other forms. Of the four potential global political responses to climate change they sketch out, one is Climate Leviathan, a planetary regulatory authority (with remarkable family resemblance to Kant's political cosmopolitanism!). Another is Climate $X$, situated social movements that transcend the planetary sovereignty and capitalism of Climate Leviathan. Its critical and radical aspects open in- 
teresting possibilities for a Deleuzian ethic of affirmative learning and democratic action, rather than global regulatory institutions to coordinate effective responses to the climate crisis and other global threats to tourism (like the current COVID-19 pandemic!).

Helpful implications arise from this for tourism pedagogy and practice, such as establishing educational programs facilitating dialogue and travel experience that open avenues for cross-cultural experiences, situated ethical encounters and critical (self-)reflection. Here, both Kantian and Deleuzian pedagogy on cosmopolitanism and global citizenship offer valuable insights. Kleingeld (1998) notes that Martha Nussbaum has drawn on Kant's moral theory for a moral version of cosmopolitanism. "This means, in educational terms, that the student in the United States, for example, may continue to regard herself as in part defined by her particular loves - for her family, her religious and/or ethnic and/or racial community or communities, even for her country. But she must also, and centrally, learn to recognize humanity wherever she encounters it, undeterred by traits that are strange to her, and be eager to understand humanity in its 'strange' guises" (Nussbaum, 1996).

It can be argued, too, that Deleuze's affirmative ethics can facilitate an alternative radical "Cosmopolitan Right" and Cosmopolitan (Global) Justice, and to this end the Deleuzian perspective offers important insights for tourism pedagogy and praxis. For Deleuze, preparatory education is necessary if we are to grasp the revolutionary potential in the encounter (Bryant, 2008). Openness to the encounter means not only an open-mindedness to perceive it, but also the willingness to seek it out in the world, in one's habits of interpretation, and in the ways of living one presupposes. It is a daring to know, a daring to learn and a daring to grow. It is a willingness to inhabit perspectives and situations other than those valued as powerful, which "is critical for deterritorialising not just patriarchal binary oppositions, but all normalisations and molar categories" (Carr, 2018: 205).

The confrontation with implicit biases can be a difficult process, however. An analysis of your own implicit biases forces you come face to face with the fact that you may not be the person you thought you were. This is why, for Deleuze and Guattari, resistance to fascism must start from within: "it is too easy to be antifascist on the molar level, and not even see the fascist inside you, the fascist you yourself sustain and nourish and cherish with molecules

Deleuze's approach may usefully inform critical tourism pedagogies like that of Boluk, Cavaliere \& Duffy's (2019) work on empowering the critical tourism citizen. 
both personal and collective" (Deleuze and Guattari, 1987: 214-215). Deleuze seeks within pedagogical practice an "ethics without morality that aims at transcending or overcoming one's mode of habitual belief and implicit bias so as to make possible a new mode of self-becoming-other through negotiations across differences and the capacity of becoming affected by experiences foreign to one's own" (Carr, 2018: 43); where others are never imprisoned and where multiple perspectives are allowed to unfold. Therefore this ethics does not entail the imposition of a constraining set of values onto others. It is not the authoritarianism of fascistic thinking. On the contrary, what it supports is the possibility of achieving integrity and authenticity within our fluid and imbricated selves by opening up to sharing the life-worlds of others.

Looking forward, the Kantian-Deleuzian frame merits further exploration in tourism studies with respect to global coordination and regulation of crises like pandemics and climate change. Ethical frameworks coexist and changes in the dominant ethics are always slow. Posthumanist pedagogies and experiential education practices that immerse visitors and students in the voices and perspectives of diverse people, animals and the earth, encourage the cultivation of empathy, growth and creative critical thinking while eluding the recreation of a canon of beliefs that colonises ears, vision and minds. The more posthumanist pedagogies are fostered among travelers, hosts, guests, operators and policy makers in the 21st century landscape of high mobilities and climate crisis, the more tourism can become more just, sustainable and responsive to global threats. Otherwise deontological, moralistic and coercive frameworks like the traditional Kantian cosmopolitanism will not be able to curb the current unsustainable outcomes and will continue to be co-opted by capitalist neo-liberalism.

\section{BIBLIOGRAPHY}

Alston, Philip (2019). Climate change and poverty: report of the special rapporteur on extreme poverty and human rights, Report presented to the UN Human Rights Council Forty-first session, 24 June - 12 July, A/ HRC/41/39. Retrieved from: https://www.ohchr.org/EN/NewsEvents/Pages/DisplayNews.aspx?N ewsID=\%2024735\&LangID=E. 
Bianchi, Raoul \& de Man, Frans de (2020). Tourism, inclusive growth and decent work: a political economy critique, Journal of Sustainable Tourism. doi: 10.1080/09669582.2020.1730862.

Bianchi, Raoul \& Stephenson, Marcus (2014). Tourism and Citizenship: Rights, Freedoms and Responsibilities in the Global Order. New York, NY: Routledge.

Bohman, James \& Lutz-Bachmann, Matthias (Eds.) (1997). Essays on Kant's Cosmopolitan Ideal. New Baskerville, USA: MIT Press.

Boluk, Karla A., Cavaliere, Christina T. \& Duffy, Lauren N. (2019). A pedagogical framework for the development of the critical tourism citizen, Journal of Sustainable Tourism, 27(7), 865-881. doi: 10.108o/og669582.2019.1615928

Braidotti, Rosi \& Pisters, Patricia (Eds.) (2012). Revisiting Normativity with Deleuze. London, New York: Bloomsbury.

Britton, Stephen (1982). The political economy of tourism in the Third World. Annals of Tourism Research, 9, 331-358.

Bryant, Levi (2008). Difference and givenness: Deleuze's transcendental empiricism and the ontology of immanence. Evanston: Northwestern University Press.

Carr, Cheri Lynne (2018). Deleuze's Kantian Ethos: Critique as a way of life. Edinburg: Edinburg University Press.

Colebrook, Claire (2012). Norm Wars. In Braidotti, Rosi and Pisters, Patricia (Eds.). Revisiting Normativity with Deleuze (81-97). London, New York: Bloomsbury.

Deleuze, Gilles (1994). Difference and Repetition. New York: Columbia University Press.

Deleuze, Gilles (2008). Kant's Critical Philosophies: The Doctrine of the Faculties. London: The Anthalone Press. Hugh Tomlinson and Barbara Habberjam (trans.).

Deleuze, Gilles \& Guattari, Felix (1987). A Thousand Plateaus: Capitalism and Schizophrenia. Minneapolis: University of Minnesota Press.

Dredge, Dianne \& Jenkins, John (Eds.) (2016). Stories of Practice: Tourism policy and planning. New York: Routledge. 
Edgell, David L., Allen, Maria D., Smith, Ginger \& Swanson, Jason R. (2008). Political and foreign policy implications of tourism. In Edgell, David L., Allen, Maria D., Smith, Ginger and Swanson, Jason (Eds.). Tourism Policy and Planning: Yesterday, Today, Tomorrow (141180). Oxford, UK: Butterworth-Heinemann.

Escobar, Arturo (2018). Designs for the Pluriverse. Durham: Duke University Press.

Fraser, Nancy (2010). Scales of justice: Reimagining political space in a globalizing world. New York: Columbia University Press.

Gössling, Stefan, Scott, Daniel \& Hall, Colin Michael (2020). Pandemics, tourism and global change: a rapid assessment of COVID-19. Journal of Sustainable Tourism. doi: 10.1080/o9669582.2020.1758708.

Guia, Jaume (2020). Conceptualizing justice tourism and the promise of posthumanism. Journal of Sustainable Tourism. Special issue on justice and tourism. Jamal, Tazim and Higham, James (Eds.), forthcoming. doi: 10.108o/og669582.2020.1771347.

Habermas, Jürgen (1997). Kant's Idea of Perpetual Peace, with the Benefit of Two Hundred Years Hindsight. In Bohman, James and LutzBachmann, Matthias (Eds). Essays on Kant's Cosmopolitan Ideal (113154). New Baskerville, USA: MIT Press.

Hall, Colin Michael (2011). A typology of governance and its implications for tourism policy analysis. Journal of Sustainable Tourism, 19(45), 437-457.

Haraway, Donna (2008). When Species Meet. Minneapolis: The University of Minnesota Press.

Harvey, David (1990). The Condition of Postmodernity. Cambridge, MA: Blackwell.

Horkheimer, Max \& Adorno, Theodore (2002). In Noerr, G. S. (Ed.). Dialectic of Enlightenment: Philosophical Fragments. Stanford: Stanford University Press.

Horowitz, Jason (2020). Venice glimpses a future of future tourists and likes what it sees. New York Times, June 3, 2020. Retrieved from: 
https://www.nytimes.com/2020/o6/o3/world/europe/coronavirusvenice-tourists.html.

Jamal, Tazim (2019). Justice and Ethics in Tourism. London and NY: Routledge.

Kant, Immanuel (1784/2006). Idea for a Universal History from a Cosmopolitan Perspective. In Kleingeld, Pauline (Ed.). Toward Perpetual Peace and Other Writings on Politics, Peace, and History (3-16). New Haven: Yale University Press. David Colclasure (trans.).

Kant, Immanuel (1785/1996). Groundwork of the Metaphysics of Morals. In Gregor, Mary (Ed. and trans.). Immanuel Kant: Practical Philosophy (37-108). Cambridge: Cambridge University Press.

Kant, Immanuel (1793/1996). On the Common Saying: This May be True in Theory but it is of no use in practice. In Gregor, Mary (Ed. and trans.). Immanuel Kant: Practical Philosophy (273-310). Cambridge: Cambridge University Press.

Kant, Immanuel (1795/1996). Toward Perpetual Peace: A Philosophical Sketch. In Gregor, Mary (Ed. and trans.). Immanuel Kant: Practical Philosophy (311-352). Cambridge: Cambridge University Press.

Kleingeld, Pauline (1998). Kant's Cosmopolitan Law: World Citizenship for a Global Order. Kantian Review, 2, 72-90.

Kleingeld, Pauline (ed.) (2006). Kant, Immanuel, Toward Perpetual Peace and Other Writings on Politics, Peace, and History. New Haven: Yale University Press. David L. Colclasure (trans.).

Kleingeld, Pauline \& Brown, Eric (2014). Cosmopolitanism. In Ed Zalta (Ed.). The Stanford Encyclopedia of Philosophy (Fall). Retrieved from: https://plato.stanford.edu/archives/fall2014/entries/cosmopolitanis $\mathrm{m} /$.

López-González, José Luis (2018). From the Ethical Code to the International Convention. A Critical Panorama of The World Tourism Organization from the Cosmopolitanism Perspective. Oxímora. Revista Internacional de ética, 12, 205-223. doi: 10.1344/oxi.2018.112.20598 (Title translated) 
Mair, Judith, Ritchie, Brent \& Walters, Gabby (2016). Towards a research agenda for post-disaster and post-crisis recovery strategies for tourist destinations: a narrative review. Current Issues in Tourism, $19(1), 1-26$.

Modern Diplomacy (2020). UNWTO convenes Global Tourism Crisis Committee. Newsroom, March 26, 2020. https://moderndiplomacy.eu/2020/o3/26/unwto-convenes-globaltourism-crisis-committee/.

Mowforth, Martin \& Munt, Ian (2016). Tourism and Sustainability: Development, globalisation and new tourism in the Third World. London and New York: Routledge.

Novelli, Marina, Burgess, Liv G., Jones, Adam \& Ritchie, Brent W. (2018). 'No ebola... still doomed'-The ebola-induced tourism crisis. Annals of Tourism Research, 70, 76-87.

Nussbaum, Martha (1996). Patriotism and cosmopolitanism. In Cohen, Joshua (Ed.). For Love of Country: Debating the Limits of Patriotism (317). Boston: Beacon Press. Also online: http://bostonreview.net/martha-nussbaum-patriotism-andcosmopolitanism.

Nussbaum, Martha (2019). The Cosmopolitan Tradition: A Noble but Flawed Ideal. Cambridge, MA: Harvard University Press.

Rawls, John (1993). The Law of Peoples. Critical Inquiry, 20(1), 36-68.

Swain, Margaret Byrne (2009). The Cosmopolitan Hope of Tourism: Critical Action and Worldmaking Vistas. Tourism Geographies, $11(4)$, 505-525. doi: 10.1080/14616680903262695.

Swain, Margaret Byrne (2013). Chinese Cosmopolitanism (Tianxia He Shijie Zhuyi) in China's Heritage Tourism. In Blumenfield, Tami and Silverman, Helaine (Eds). Cultural Heritage Politics in China (3350). New York, NY: Springer. https://doi.org/10.1007/978-1-4614$6874-5-3$.

The Economist (2020). The New World Disorder. June 18th 2020 edition. https://www.economist.com/leaders/2020/o6/18/the-newworld-disorder. 
Wainwright, Joel \& Mann, Geoff (2018). Climate Leviathan: A political theory of our planetary future. London: Verso.

Wood, Robert E. (2009). Tourism and International Policy: NeoLiberalism and beyond. In Jamal, Tazim and Robinson, Mike (Eds.). The SAGE Handbook of Tourism Studies (595-612). Thousand Oaks, CA: SAGE.

World Health Organization (2020). A Joint Statement on Tourism and COVID-19 - UNWTO and WHO Call for Responsibility and Coordination. 27 February, 2020. Newsroom. Retrieved from: https://www.who.int/news-room/detail/27-02-2020-a-jointstatement-on-tourism-and-covid-19---unwto-and-who-call-forresponsibility-and-coordination.

Young, Iris Marion (2006). Responsibility and global justice: A social connection model. Social Philosophy and Policy, 23(1), 102-130. 
32 RECERCA · DOI: http://dx.doi.org/10.6035/Recerca.2021.26.1.2 - ISSN electrónico: 2254-4135 - pp. 9-31 